\title{
NATURAL DURABILITY OF Cedrus atlantica WOOD RELATED TO THE BIOACTIVITY OF ITS ESSENTIAL OIL AGAINST WOOD DECAYING FUNGI
}

\author{
Abdelwahed Fidah ${ }^{1,4,4}$, Noura Salhi', Mohamed Rahouti ${ }^{1}$, Bousselham Kabouchi' \\ Mohsine Ziani ${ }^{3}$,Mohamed Aberchane ${ }^{4}$, Abderrahim Famiri ${ }^{4}$
}

\begin{abstract}
The Atlas cedar, Cedrus atlantica is a resinous species of Pinaceae originated from North Africa and well known for its noble timber. This work was conducted to assess the natural durability of its wood, to study the chemical composition of essential oil extracted from its sawdust wood and to test the bioactivity of this essential oil against four wood decaying fungi: Gloeophyllum trabeum, Oligoporus placenta, Coniophora puteana and Trametes versicolor. The assessment of natural durability of wood was conducted according to the methods described in the European standards, CEN/TS 15083-1 and NF EN 350-1. Mass losses of wood specimens, after 16 weeks of exposure to fungi attack, in laboratory test, showed that Cedrus atlantica wood is very durable to durable against wood decay fungi attack. The extraction of essential oil from sawdust by hydro-distillation yielded about 3,35\% and the chemical analysis of this essential oil by GC-MS showed that E- $\gamma$-Atlantone (19,73\%); E- $\alpha$ Atlantone (16,86\%), 5-Isocedranol (11,68\%); 9-iso-Thujopsanone (4,45\%); Cedranone $(4,13 \%)$ and Z $\alpha$-Atlantone $(4,02 \%)$ were the main major identified components. The antifungal activity tested by the direct contact technique on agar medium showed a strong inhibition of wood decaying fungi, especially Gloeophyllum trabeum inhibited at 1/1000 v/v concentration.
\end{abstract}

Keywords: Antifungal activity, chemical analysis, essential oils, natural durability, sawdust wood, wood decaying fungi.

\section{INTRODUCTION}

The genus Cedrus, belonging to the family of Pinaceae, includes four species: Cedrus atlantica, $C$. libani, C. brevifolia and C. deodora. The natural range of Cedrus atlantica Manetti is mainly limited to the Algerian and Moroccan mountains (Boudy 1950, Arbez et al. 1978). In Morocco, the Atlas cedar covers an area of approximately 132000 hectares located mainly in the Middle Atlas. It annually provides between 80000 and $100000 \mathrm{~m}^{3}$ of wood logs intended for sawing and veneer. This production represents approximately $90 \%$ of timber of the total production of the country (HCEFLCD 2013). C. atlantica wood is ranked among half-heavy to heavy woods, with basic density, at $12 \%$ moisture, of $530 \mathrm{~kg} / \mathrm{m}^{3}$; a total volumetric shrinkage of approximately $11,26 \%$. It has a better dimensional stability and has an easy drying, with axial compression strength of 48,8 $\mathrm{MPa}$, shear strength of $13,6 \mathrm{MPa}$; a static flexural modulus of $10101 \mathrm{MPa}$ and a rupture under static bending modulus of $94 \mathrm{MPa}(\mathrm{El}$ Azzouzi and Keller 1998). Its heartwood is very durable to durable against wood-decay fungi (Brunetti et al. 2001).

\footnotetext{
${ }^{1}$ Laboratoire de Botanique, Mycologie et Environnement, Faculté des Sciences, Mohammed V University in Rabat, Rabat, Morocco. fidah.abdelwahed@gmail.com

${ }^{2}$ Equipe de Spectronomie Moléculaire, Optique et Instrumentation Laser, Faculté des Sciences, Mohammed V University in Rabat, Rabat, Morocco.

${ }^{3}$ Institut National des Sciences de l'Archéologie et du Patrimoine, Rabat, Morocco.

${ }^{4}$ Laboratoire de Durabilité et d'Anatomie, Service de Technologie de Bois et de Valorisation des Produits Forestiers, Centre de recherche Forestière, Rabat, Morocco.

•Corresponding author: fidah.abdelwahed@gmail.com

Received: 09.10.2015 Accepted: 22.06.2016
} 
Sawing and processing of Cedar wood however generate a lot of waste in form of slabs and sawdust. The last waste form is estimated at about $8 \%$ of sawn timber and it represents an important source of essential oils with yields ranging from 2,6 to 5,6\% depending on the source and the health of the wood (Aberchane et al. 2004, Aberchane et al. 2006). Essential oils of cedar, rich in terpenes, were used in perfumery and in the development of many active substances (Adams 1991). Recent studies, on essential oils extracted from cedar wood, highlighted the antimicrobial, antifungal and insecticide effects of these essential oils (Hmamouchi et al. 2001, Macchioni et al. 2002, Satrani et al. 2006, Aberchane 2010, Derwich et al. 2010). The use of essential oils extracted from many aromatic and medicinal plants as an agent for wood preservation against wood decay fungi remains little experienced (Haluk and Roussel 2000, El Ajjouri et al. 2008, Hassane et al. 2012).

Relationship between the natural durability of cedar wood and its essential oil bioactivity was not previously related. For this purpose, the present work is to assess the natural durability of $C$. atlantica wood related to the chemical composition and bioactivity of its sawdust wood essential oil against wood decaying fungi with a view to later experiment as a preservative treatment for less durable woods.

\section{MATERIALS AND METHODS}

\section{Determination of the natural durability of Cedrus atlantica wood}

In this study, C. atlantica (Manetti ex Endl. Carrière), wood originated from Azrou region (Middle Atlas Mountains, Morocco), was tested and compared to the Scots pine, Pinus sylvestris L., sapwood, used as reference wood. Cedar wood specimens of $(2,5 \mathrm{~cm}$ width, in radial direction $\times 1,5 \mathrm{~cm}$ thick, in tangential direction $\times 5 \mathrm{~cm}$ length, in longitudinal direction) were randomly carried from central plates (heartwood) cut in timbers of three trees aged about 90 to 100 years. For biological test, thirty Cedar wood specimens and ten others of Scots pine wood were used for each fungus test. Ten other specimens of these woods were also used for conditioning test. The reference sapwood specimens were carried from untreated commercial Scots pine wood. All specimens were free of cracks, discoloration, biological attack, insect holes and other defects.

Before the test, all specimens were put into a climatic chamber $\left(20 \pm 2{ }^{\circ} \mathrm{C}\right.$ and $65 \pm 5 \%$ relative humidity) in order to reach the wood moisture equilibrium content of $12 \%$.

The three brown rot fungi strains used in this study were Gloeophyllum trabeum BAM Ebw.109, Oligoporus placenta (ex Poria placenta) FPRL. 280, and Coniophora puteana BAM Ebw. 15, maintained in the mycological collection of the Laboratory of Botany, Mycology and Environment, Faculty of Sciences, Rabat, Morocco.

The assessment of the natural durability of $C$. atlantica wood is determined according to the European standards: CEN/TS 15083-1 (2005) and NF EN 350-1 (1994). Resistance of woods specimens to fungal decay is based on their mass loss value after fungi exposition in laboratory test compared to those of Scots pine sapwood recognized non-durable against the wood decaying fungi.

The standard CEN/TS 15083-1 previews, before fungi exposition, the calculation of the theoretical oven-dry mass $\left(M_{t o}\right)$ of biological test specimens and the $K$ coefficient of moisture correction, obtained from the measurement of the moisture content on another series of ten conditioning specimens of each wood oven dried at $103^{\circ} \mathrm{C}$ for 24 hours, as indicate:

$$
\begin{aligned}
& U(\%)=\frac{\left(M_{h}-M_{o}\right)}{M_{o}} * 100 \\
& K=\frac{100}{\left(100+U_{\text {moy }}(\%)\right)}
\end{aligned}
$$


where $M_{h}$ is initial mass at $12 \%, M_{o}$ is anhydrous mass, $U(\%)$ is moisture content of each specimen and $U_{m o v}$ is mean of moisture content of ten specimens of each type of wood. The theoretical anhydrous mass $\left(M_{t o}\right)$ of specimens intended for biological tests, is then determined as follows:

$$
M_{t o}=M_{h} * K
$$

Fungal strains used in this study were grown in Petri dishes on malt-agar medium (4\% malt extract and 3\% agar in distilled water) and then transferred after 10 to 15 days on the same medium in 500 $\mathrm{ml}$ square section bottles. Each bottle, containing $30 \mathrm{ml}$ of the medium, was inoculated with fungi and plugged with cotton. Wood specimens test were at first sterilized by autoclaving at $121{ }^{\circ} \mathrm{C}$ for 20 minutes and were exposed to fungal mycelium in bottles after about 20 days of mycelium culture, at the rate of two specimens per bottle. A small round pellets stainless steel of $2 \mathrm{~mm}$ thick, used as holders, were placed between the mycelium surface and wood specimens bottom surface. Wood moisture must be above $20 \%$ for suitable wood colonization by the mycelium. Specimens exposed to mycelia were then incubated in a dark climatic chamber $\left(\mathrm{RH}=70 \pm 5 \%\right.$ and $\left.\mathrm{T}=22 \pm 2{ }^{\circ} \mathrm{C}\right)$ during 16 weeks. At the end of incubation period, the woods specimens were removed from the culture bottles, carefully brushed and immediately weighed to determine their final moisture content before oven dried at $103^{\circ} \mathrm{C}$ for 24 hours and weighed again to determine their final anhydrous mass $\left(M_{f}\right)$. The mass losses of all inoculated specimens and the average mass loss for each fungus is then determined.

The mass loss, in percentage, of each biological test specimen is calculated as indicate:

$$
P=\frac{\left(M_{t}-M_{f}\right)}{M_{b}} * 100
$$

$M_{t o}$ and $M_{f}$ are respectively initial theoretical anhydrous mass and final anhydrous mass of wood specimens, and the means of mass loss of the biological test specimens $\left(C\right.$. atlantica wood, $\left.P_{e}\right)$ and the mean of reference wood (Scots pine sapwood, $P_{r}$ ) are calculated as follows:

$$
P_{e, r}=\frac{\left(\sum M_{b}-\sum M_{f}\right)}{\sum M_{b}} * 100
$$

The durability index " $\mathrm{X}$ " of $C$. atlantica wood is therefore:

$$
X=\frac{P_{e}}{P_{r}}
$$

and durability classes of cedar wood are then deducted from the Table 1.

Table 1. Classes of wood durability to brown-rot fungi according to standard NF EN 350-1.

\begin{tabular}{|c|c|c|}
\hline Durability class (DC) & Description & Results expressed in $\mathbf{X}^{*}$ value \\
\hline 1 & Very durable & $X \leq 0,15$ \\
\hline 2 & Durable & $0,15<\mathrm{X} \leq 0,30$ \\
\hline 3 & Moderately durable & $0,30<\mathrm{X} \leq 0,60$ \\
\hline 4 & Less durable & $0,60<\mathrm{X} \leq 0,90$ \\
\hline 5 & Non-durable & $\mathrm{X}>0,90$ \\
\hline
\end{tabular}

\footnotetext{
$* X$ is the durability index expressed as mass loss of the test specimens / mass loss of the reference specimens.
} 


\section{Chemical composition of Cedrus atlantica wood essential oil}

Three composite samples of sawdust were collected from Cedar wood sawmill of Azrou (Middle Atlas Mountains of Morocco) in heaps of waste on site. The sawdust was then sieved in laboratory to obtain a particle size of $1 \mathrm{~mm}$ and prepared for the essential oil extraction.

Three extraction assays of $150 \mathrm{~g}$ of sawdust were carried out by hydro-distillation in a Clevenger apparatus for 4 hours. Essential oil obtained was then stored in a small dark glass bottle at $4^{\circ} \mathrm{C}$ until use. Essential oils yield, expressed in $\mathrm{ml} / 100 \mathrm{~g}$ dry matter, was determined related to mean sawdust humidity of three $30 \mathrm{~g}$ samples dried at $60^{\circ} \mathrm{C}$ for 24 hours.

The chemical analysis and components identification were performed by an electronically controlled pressure gas chromatograph (GC) coupled with a mass spectroscope (MS). Gas chromatography analyses were performed with a Hewlett-Packard (HP 6890), equipped with a capillary column HP-5

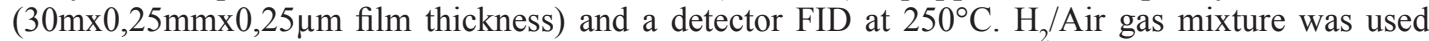
in split-splitless injector heated at $250^{\circ} \mathrm{C}$. The vector gas used was $\mathrm{N}_{2}$ with $1,5 \mathrm{ml} / \mathrm{min}$. The column temperature was programmed from $50^{\circ} \mathrm{C}$ to $250^{\circ} \mathrm{C}$ at $4^{\circ} \mathrm{C} / \mathrm{min}$. The injected volume of essential oil was $1 \mu \mathrm{l}$ diluted in $\mathrm{n}$-hexane. A standard solution of n-alkanes (C8-C26) was used to obtain the retention indices. Individual volatile components were identified by comparison of their mass spectra (MS) and retention indices (RI) with those reported in literature and also to the Adams Registry of Mass Spectral Data (Adams 1995).

\section{Bioactivity of Cedrus atlantica wood essential oil}

The four wood decay basidiomycete fungi used in the biotest were brown wood rots agents (Gloeophyllum trabeum, Oligoporus placenta and Coniophora puteana) and a white rot fungus (Trametes versicolor, CTB 863 A strain). They were chosen for the significant damages that they cause to wood and wood-based products.

The antifungal activity of Cedar essential oil was performed by direct contact on agar medium according to the method reported by Remmal et al. (1993). In order to give the essential oil a homogeneous distribution in the medium, the oil was first emulsified in a sterile solution of wateragar at $0,2 \%(\mathrm{SA})$. To test tubes containing $13,5 \mathrm{ml}$ of malt-agar medium $(20 \mathrm{~g} / \mathrm{l}$ malt extract and 15 $\mathrm{g} / \mathrm{l}$ agar), sterilized in an autoclave and kept at $45^{\circ} \mathrm{C}$ in a water bath, were added aseptically $1,5 \mathrm{ml}$ of different dilutions prepared so as to obtain final dilutions of essential oil in the culture medium of $1 / 250,1 / 400,1 / 500,1 / 800,1 / 1000,1 / 1200,1 / 2000$ and $1 / 3000$. The tubes were shaken vigorously and poured into Petri dishes. Similarly, control plates containing 13,5 $\mathrm{ml}$ of culture medium and agar solution at $0,2 \%$ (SA) alone were prepared. Petri dishes were inoculated by depositing two square fragments of $0,5 \mathrm{~cm}^{2}$, taken from a mycelial mat of a culture of 10 days in malt-agar. Three replicates for each treatment and fungus were prepared and incubated in the dark for 7 days at a temperature of 22 ${ }^{\circ} \mathrm{C}$. This biotest allows us also to determine the minimum inhibitory concentration (MIC) of essential oil for each fungus tested. The MIC is defined as the lowest concentration for which no growth of the fungus was visually observed (Tantaoui-Elaraki et al. 1992).

\section{RESULTS AND DISCUSSION}

\section{Natural durability of Cedrus atlantica wood}

C. atlantica wood specimens showed no apparent decay by the three tested wood decaying fungi and mass losses are below 4,8\% (Table 2). According to our results, this wood is therefore very durable against two fungi, G. trabeum and $O$. placenta (durability class, DC1) and durable against C. puteana (DC 2). However in view of practical use of the Cedrus wood, further resistance studies should include test fungi with preference for the durable heartwood of pines, like the brown-rot fungi, Lentinus lepideus. 
The definition of biological risks, according to the standard NF EN 335-2 (2013), is generally taken as a reference in the elaboration of the conditions of end-use of a given wood. A correspondence is then established between natural durability classes and the risk of biological attacks classes (NF EN 460 Standard, 1994). Taking into account this correspondence, natural durability classes (DC 1 and DC 2) of $C$. atlantica wood against wood-destroying fungi, allows this wood to access high-risk classes of biological attacks 4 and 5 for an end-use without preservative treatment, but only regarding decay fungi.

Compared to other coniferous woods, natural durability of $C$. atlantica wood is similar to that of the Atlas Cedar heartwood originated from young Italian plantations, considered as very durable to durable against wood decay fungi (DC 1 and DC 2) (Brunetti et al. 2001) and is better than the Aleppo pine timber considered as less durable (DC 4) (Thevenon et al. 2012).

Table 2. Mass loss of the test specimens of $C$. atlantica wood and durability classes (DC) according to EN 350-1 in brown-rot test.

\begin{tabular}{|lcccccc|}
\hline & Min \% & Max \% & Mean \% & SD \% & $\boldsymbol{X}^{* * *}$ value & DC $^{* * * *}$ \\
\hline O. placenta & 3,555 & 6,838 & 4,745 & 0,868 & 0,1437 & 1 \\
\hline C. puteana & 3,230 & 5,233 & 4,556 & 0,468 & 0,1834 & 2 \\
\hline G. trabeum & 3,163 & 5,693 & 4,290 & 0,622 & 0,1054 & 1 \\
\hline
\end{tabular}

(SD standard deviation, $\mathrm{n}=30$, for reference specimens ${ }^{*} \mathrm{n}=10$ )

* Means of mass loss of reference specimens (Scots pine sapwood) were respectively $33 \%$ for O. placenta, $25 \%$ for C. puteana and $41 \%$ for G. trabeum,

** Durability index.

*** Durability class.

\section{Chemical composition of Cedrus atlantica wood essential oil}

The extraction of essential oil by hydro-distillation of Atlas cedar sawdust wood, having a moisture content of about $14,5 \%$; gave an average yield of essential oil of 3,4\%. This is slightly higher than that obtained by the steam stripping distillation (2,4\%) reported by Aberchane et al. 2001. The yields of Cedar wood essential oil varies greatly depending on the forest source (Aberchane et al. 2004), and the part of tree used (Derwich et al. 2010, Rhafouri et al. 2014). Indeed, distillation needles yielded about $1,8 \%$ while the seeds gave yields between 2,6 and 3,6\% (Derwich et al. 2010). Low yields $(0,05$ to $0,49 \%$ ) were reported by Paoli et al. 2011 for essential oils extracted from small branches of $C$. atlantica originated from different localities of Corsica.

Chemical analysis of cedar wood essential oil, by GC-MS permits to identify 41 major components $(95,69 \%)$ mainly as ketones $(52,05 \%)$ and alcohols $(26,58 \%)$ (Table 3$)$. This essential oil is dominated by E- $\gamma$-Atlantone $(19,73 \%)$, E- $\alpha$ - Atlantone (16,86\%), 5-Isocedranol (11,68\%), 9-iso-Thujopsanone $(4,45 \%)$, Cedranone (4,13\%), Z- $\alpha$-Atlantone (4,02\%), Cedroxyde (2,38\%) and 14-Hydroxy- $\delta$-Cadinene $(1,94 \%)$ (Table 3). This composition is similar to that published by Aberchane et al. 2006 using the same extraction method. However, the steam stripping method for the same material revealed that the himachalenes $(53 \%)$ were major constituents rather than the $\alpha$-atlantones $(14 \%)$. This difference in the essential oil composition is due to the extraction method, but also the duration and the distillation temperature can significantly influence the chemical composition of essential oils extracted (Janssen et al. 1987, Lachowicz et al. 2003).

Furthermore, the essential oil extracted from the needles was dominated by $\alpha$-pinene $(14,85 \%)$, $\gamma$-himachalene $(10,14 \%)$ and $\beta$-himachalene $(9,89 \%)$. While the major components of the essential oil of the non-winged seeds were $\alpha$-pinene $(46,16 \%)$, manool $(25,47 \%)$, bornyl acetate $(10,18 \%)$, $\beta$-pinene $(5,95 \%)$ and $\alpha$-terpinene $(2,71 \%)$, those of winged seeds essential oil were manool $(49,02 \%)$ , $\alpha$-pinene (40,82\%), 6-comphenol (2,52\%) and $\beta$-pinene (2,13\%) (Derwich et al. 2010, Rhafouri et al. 2014). Essential oils extracted from small branches of $C$. atlantica originated from different localities of Corsica were also dominated by $\alpha$-pinene (up to 79,4\%), himachalol (up to 66,2\%), $\beta$-pinene (up 
to $21,49 \%$ ), $\beta$-himachalene (up to $19,3 \%$ ), $\gamma$-himachalene (up to $11,0 \%$ ), and $\alpha$-himachalene (up to 10,9\%) (Paoli et al. 2011).

Table 3. Chemical analysis of Cedrus atlantica wood essential oil from Azrou region, the 41 major identified components.

\begin{tabular}{|c|c|c|c|c|}
\hline Major Component & RT(mn) & CKI & LKI & PA (\%) \\
\hline Neo-3-Thujanol & 15,466 & 1149,20 & 1143 & 1,28 \\
\hline Turmoil & 30,267 & 1579,30 & 1578 & 3,44 \\
\hline Carotol & 30,715 & 1593,61 & 1594 & 0,21 \\
\hline Cedrol & 30,933 & 1600,61 & 1596 & 1,90 \\
\hline Widdrol & 31,059 & 1604,86 & 1597 & 0,52 \\
\hline 1-Epicubenol & 31,291 & 1612,68 & 1614 & 0,40 \\
\hline Himachalol & 32,188 & 1642,93 & 1647 & 2,45 \\
\hline$\alpha$-Cadinol & 32,693 & 1659,97 & 1653 & 0,15 \\
\hline 5-Isocedranol & 32,951 & 1668,67 & 1669 & 11,68 \\
\hline Z-trans Bergamotol & 33,523 & 1687,96 & 1693 & 0,45 \\
\hline Kusimol & 34,860 & 1734,56 & 1736 & 0,51 \\
\hline$\beta$-Santalol & 35,081 & $\mathbf{1 7 4 2 , 3 5}$ & 1741 & 1,98 \\
\hline Z-Epi- $\beta$-Santalol & 36,859 & 1805,04 & 1809 & 0,49 \\
\hline E-Z-Farnesol & 35,306 & 1750,28 & 1742 & 1,12 \\
\hline \multicolumn{2}{|l|}{ Total Alcohols } & & & 26,58 \\
\hline Hexyl Isobutyrate & 15,568 & 1151,92 & 1150 & 1,38 \\
\hline Z-Lingustilide & 34,708 & 1729,20 & 1730 & 0,44 \\
\hline Benzyl Benzoate & 35,784 & 1767,14 & 1762 & 1,16 \\
\hline E-Ligustilide & 36,479 & 1791,64 & 1790 & 0,32 \\
\hline Z- $\beta$-Santalol Acetate & 37,245 & 1819,62 & 1823 & 1,15 \\
\hline Z-Ternine & 37,788 & 1839,76 & 1838 & 1,25 \\
\hline \multicolumn{2}{|l|}{ Total Esters } & & & 5,69 \\
\hline Camphor & 15,466 & 1149,20 & 1143 & 1,28 \\
\hline Cedranone & 31,608 & 1623,37 & 1620 & 4,13 \\
\hline 9-iso-Thujopsanone & 31,867 & 1632,11 & 1637 & 4,45 \\
\hline 3-Thujopsanone & 32,479 & 1652,75 & 1650 & 0,52 \\
\hline Deodarone & 33,235 & 1678,25 & 1694 & 1,07 \\
\hline E $\gamma$-Atlantone & 34,055 & 1706,17 & 1701 & 19,73 \\
\hline $\mathrm{Z} \alpha$-Atlantone & 34,411 & 1718,72 & 1713 & 4,02 \\
\hline $\mathrm{E} \alpha$-Atlantone & 36,215 & 1782,33 & 1773 & 16,86 \\
\hline \multicolumn{2}{|c|}{ Total Ketones } & & & 52,05 \\
\hline Trans Rose Oxyde & 14,791 & 1131,20 & 1127 & 0,37 \\
\hline Oxydo himachalene & 30,051 & 1572,40 & 1574 & 0,22 \\
\hline$\beta$-Himachalene Oxyde & 31,166 & 1608,47 & 1611 & 0,41 \\
\hline Cedroxyde & 34,194 & $\mathbf{1 7 1 1 , 0 7}$ & 1704 & 2,38 \\
\hline \multicolumn{2}{|c|}{ Total oxydes } & & & 3,37 \\
\hline Epi-Cedrane & 25,956 & 444,56 & 1441 & 0,33 \\
\hline$\beta$-Himachalene & 27,838 & 1501,69 & 1499 & 0,79 \\
\hline$\alpha$-Deshydro-ar-Himachlene & 28,255 & 1515,02 & 1511 & 1,13 \\
\hline$\delta$ - Cadinene & 28,545 & 1524,28 & 1524 & 0,31 \\
\hline$\gamma$-Deshydro-ar-Himachlene & 28,73 & 1530,19 & 1529 & $\mathbf{1 , 5 7}$ \\
\hline$\alpha$-Calacorene & 29,171 & 1544,28 & 1542 & 0,58 \\
\hline$\beta$ - Calacorene & 29,804 & 1564,50 & 1563 & 0,35 \\
\hline 14 Hydroxy-Murolene & 36,328 & 1786,32 & 1775 & 1,00 \\
\hline 14-Hydroxy- $\delta$ - Cadinene & 36,684 & $\mathbf{1 7 9 8 , 8 7}$ & 1799 & 1,94 \\
\hline Total Terpenes & & & & 7,99 \\
\hline Global & & & & 95,69 \\
\hline
\end{tabular}

RT Retention time. LKI Literature Kovàts Index. CKI Calculated Kovàts Index.PA. Peak Area in \%. 


\section{Bioactivity of Cedrus atlantica wood essential oil}

The Atlas cedar wood essential oil showed clearly significant antifungal activity against the four wood decaying fungi tested (Table 4). G. trabeum fungus was the most sensitive to inhibitory effect of this essential oil since it was inhibited from a concentration of $1 / 1000 \mathrm{v} / \mathrm{v}$. While a concentration of $1 / 800 \mathrm{v} / \mathrm{v}$ was sufficient to inhibit the growth of T. versicolor. However, C. puteana and O. placenta were the most resistant, their growth inhibition was not noticeable until 1/400 concentrations (Table 4).

Table 4. Antifungal activity of Cedrus atlantica sawdust essential oil.

\begin{tabular}{|l|c|c|c|c|c|c|c|c|c|}
\hline Concentration v/v & $1 / 250$ & $\mathbf{1 / 4 0 0}$ & $\mathbf{1 / 5 0 0}$ & $\mathbf{1 / 8 0 0}$ & $\mathbf{1 / 1 0 0 0}$ & $\mathbf{1 / 1 2 0 0}$ & $\mathbf{1 / 2 0 0 0}$ & $\mathbf{1 / 3 0 0 0}$ & $\mathrm{C}$ \\
\hline T. versicolor & - & - & - & MIC & + & + & + & + & + \\
\hline C. puteana & - & MIC & + & + & + & + & + & + & + \\
\hline G. trabeum & - & - & - & - & MIC & + & + & + & + \\
\hline O. placenta & - & MIC & + & + & + & + & + & + & + \\
\hline
\end{tabular}

\section{Relationship between natural durability of Cedrus atlantica wood and antifungal activity of its essential oil against wood decaying fungi}

The antifungal activity of the essential oil of cedar wood can be related to its rich chemical composition essentially atlantones (about 40,61\%) which is a sesquiterpen ketones. Studies on the biological activity of some pure compounds of essential oils, such as $\alpha$-atlantones extracted from Decalepis hamiltonii, showed great inhibitory effect especially against pests (George et al. 1998) and molds (Thangadurai et al. 2002). In our study, alcohols present in significant amount (26,58\%), mainly isocedranol, tumerol, himachalol and cedrol (Table 4). May also be involved in the inhibitory effect of this essential oil. The hydrocarbon monoterpenes, such as cadinenes would also have a great antimicrobial property (Keawsa-Ard et al. 2012). Furthermore, investigations have already shown that thujaplicines (tropolones) of Thuja plicata acted strongly as fungicide substances against Basidiomycetes fungi: Coniophora puteana, Fomes pinicola, Lentinus lepideus, Serpula lacrymans, Polyporus balsameus and Poria vaporaria; and the wood blue stain fungi are also fully inhibited for concentrations in $\beta$-thujaplicine of $0,01 \%$ (Rennerfelt 1948). The volatile constituents of essential oils such as alcohols create an imbalance in one or the other of the lytic and the synthetic enzymes systems. Growth inhibition therefore follows and it is manifested by stopping natural extension of hyphae (Kahn and Andrawis 1985, Takeuchi and Ichishima 1989).

A synergistic action of two or more components of Cedar wood essential oil can also be involved in the observed bioactivity reported in our study. Furthermore, separate alcoholic and aqueous extracts of Lipia alba essential oil, did not have any fungicidal activity at any concentration in culture medium. However L. alba essential oil presented fungicide activity against the white-rot fungus, Pleurotus ostreatus (Geromini et al. 2015).

To identify the active part of Cedar wood essential oil, an antifungal activity of hydrocarbon and oxygenated fractions of this oil is under study.

Bioactivity of essential oil extracted from $C$. atlantica sawdust wood against wood decaying fungi may then explain the level of natural durability of this wood that ranged from very durable (DC1) to durable (DC2). Durability classes were positively correlated with Cedar sawdust essential oil bioactivity against the three wood-destroying fungi specified by the CEN/TS 15083-1 standard (Tables 2 and 4). G. trabeum was the most sensitive fungi to this essential oil activity and durability of this wood against the same fungus was the best one. 


\section{CONCLUSIONS}

The present study, devoted to the assessment of natural durability of Cedrus atlantica wood related to the bioactivity of its essential oil, showed that:

The wood of $C$. atlantica is very durable against two fungi. G. trabeum and $O$. placenta (durability class. DC1) and durable against C. puteana (DC 2).

The essential oil extraction from sawdust yielded about 3,4\%; and the composition of this essential oil is dominated by E- $\gamma$-Atlantone (19,73\%), E- $\alpha$ - Atlantone (16,86\%), Isocedranol $(11,68 \%)$, 9-iso-Thujopsanone (4,45\%), Cedranone (4,13\%), Z- $\alpha$ - Atlantone $(4,02 \%)$, Cedroxyde $(2,38 \%)$ and $\delta$-Cadinene $(1,94 \%)$.

The essential oil of Atlas cedar sawdust showed clearly significant antifungal activity against the four wood-destroying fungi tested. The high inhibitor oil power might be explained by the high levels of ketones especially $\gamma$ and $\alpha$-Atlantones and phenols recognized by their strong fungal inhibitory power.

The durability classes were positively correlated with sawdust essential oil bioactivity against the three wood decaying fungi.

Thus, for best valorization of $C$. atlantica sawdust, its essential oil can be tested in further studies as a wood preservative.

\section{ACKNOWLEDGEMENTS}

This manuscript is prepared from the outcome of the project titled "Local wood and wood-based products characterization", conducted by the wood technology and utilization of forest products office in Moroccan Forest Research Center. Rabat. This project is supported by Moroccan High Commission for Water and Forests and Fight against Desertification in collaboration with Faculty of Sciences, Rabat. Morocco.

\section{REFERENCES}

Aberchane, M.; Fechtal, M. ; Chaouch, A.; Bouayoune, T. 2001. Influence de la durée et de la technique d'extraction sur le rendement et la qualité des huiles essentielles du cèdre de l'atlas (Cedrus atlantica Manetti). Ann Rech For Maroc 34:110-118.

Aberchane, M.; Fechtal, M.; Chaouch, A. 2004. Analysis of Moroccan Atlas Cedarwood Oil (Cedrus atlantica Manetti). J Essent Oil Res 16:542-547.

Aberchane, M.; Fechtal, M.; Chaouch, A.; El Abid, A. 2006. Effet de l'infection du bois de Cèdre de l'atlas (Cedrus atlantica M.) par les champignons Trametes Pini et Ungulina Officinalis. Ann Rech For Maroc 37: 105-114.

Aberchane, M. 2010. Contribution à la caractérisation de la qualité des huiles essentielles du cèdre de l'Atlas marocain et étude de leur activité microbiologique. Thèse Doctorat, Fac. Sc. Kénitra, Maroc, $183 \mathrm{p}$.

Adams, R.P. 1991. Cedar wood oil. In: Modern methods of plant analysis oils and waxes. H.F. Linskens \& J.F. Jackson (eds), Springer-Verlag. p:159-173.

Adams, R.P. 1995. Identification of essential oil components by Gas Chromatography coupled with Mass Spectroscopy. Allowed published corporation, Carol Steam, Illinois, USA, 469p. 
Arbez, M.; Ferrandes, P.; Uyar, N. 1978. Contribution à l'étude de la variabilité géographique des cèdres. Ann Sci For 35(4):265-284.

Boudy, P. 1950. Economie forestière Nord-Africaine : monographie et traitement des essences forestières. Ed. Larose. T2. pp: 529-619.

Brunetti, M.; De Capua, E.; Macchioni, N.; Monachello, S. 2001. Natural durability, physical and mechanical properties of Atlas cedar (Cedrus atlantica Manetti) wood from Southern Italy. Ann For Sci 58: 607-613.

CEN/TS 15083-1. 2005. Durability of wood and wood-based products - Determination of the natural durability of solid wood against wood-destroying fungi- Test methods, Part 1: Basidiomycetes (Brussels, European Committee for Standarization).

Derwich, E.; Benziane, Z.; Boukir, A. 2010. Chemical Composition and In Vitro Antibacterial Activity of the Essential Oil of Cedrus atlantica. Int J Agric Biol 12: 381-385.

El Ajjouri, M.; Satrani, B.; Ghanmi, M.; Aafi, A.; Farah, A.; Rahouti, M.; Amarti, F.; Aberchane, M. 2008. Activité antifongique des huiles essentielles de Thymus bleicherianus Pomel et Thymus capitatus (L.) Hoffm. \& Link contre les champignons de pourriture du bois d'oeuvre. Biotechnol Agron Soc Environ 12: 345-351.

EI Azzouzi, K.; Keller, R. 1998. Propriétés technologiques du bois de cèdre de I IAtias (Cedrus atlantica Manetti). Forêt Méditerranéenne 19(1): 11-33.

George, J.; Pereira, J.; Divakar, S.; Udaysankar, K.; Ravishankar, G.A. 1998. A method for the preparation of active fraction from the root of Decalepis hamiltonii, useful as bioinsectiside. Indian Patent No. 1301/Dec/ 98, 1998.

Geromini, K.V.N.; Roratto, F.B.; Ferreira, F.G.; Camilotti, J.; Vidigal, T.M.A.; Valle, J.S.; Colauto, N.B.; Linde G.A. 2015. Fungicidal effect of Lippia alba essential oil on a white-rot fungus. Maderas-Cienc Tecnol 17(1): 29-38.

Haluk, J.P.; Roussel, C. 2000. Caractérisation et origine des tropolones responsables de la durabilité naturelle des Cupressacées. Application potentielle en préservation du bois. Ann For Sci 57: 819-829.

Hassane, S. O. S. ; Ghanmi, M.; Satrani, B.; Farah, A.; Mansouri, N.; Chaouch, A. 2012. Activité antifongique contre la pourriture du bois de l'huile essentielle de Pelargonium $x$ asperum Erthrt. Ex willd des Îles Comores. Bull Soc Roy Sc Liège 81: 36-49.

HCEFLCD, 2013. Synthèse de l'Inventaire Forestier National Marocain. Direction de développement forestier. Haut Commissariat aux Eaux et Forêts et à la Lutte Contre la Désertification, Rabat, Maroc.

Hmamouchi, M.; Hamamouchi, J.; Zouhdi, M.; Bessiere, JM. 2001. Chemical and Antimicrobial Properties of Essential Oils of Five Moroccan Pinaceae. J Essent Oil Res 13: 298-302.

Janssen, A.M.; Scheffer, J.J.C.; Baerheim, A.S. 1987. Antimicrobial activity of essential oils: a 1976-86 literature review. Aspects of test methods. Planta Med 53: 395-398.

Kahn, V.; Andrawis, A. 1985. Inhibition of mushroom tyrosinase by tropolone. Phytochemistry 24: $905-908$ 
Keawsa-Ard, S.; Liawruangrath, B.; Liawruangrath, S.; Teerawutgulrag, A.; Pyne, S. G. 2012. Chemical constituents and antioxidant and biological activities of the essential oil from leaves of Solanum spirale. Natural Product Communications 7 (7): 955-958.

Lachowicz , K.J.; Jones, G.P.; Briggs, D.R.; Bienvenu, F.E.; Palmer, M.V.; Mishra, V.; Jenny, M.; Hipwell, M.W.; Ryan, T.; Cavangh, H.M.A. 2003. Bioactivity of Backhousia citriodora: antibacterial and antifungal activity. J Agric Food Chem 51: 76-81.

Macchioni, F. ; Cioni, P.L.; Flamini, G.; Morelli, I.; Perrucci, S.; Franceschi, A.; Macchioni, G.; Ceccarini, L. 2002. Acaricidial activity of pine essential oils and their main components against Tyrophagus putrescentia, a stored food mite. J Agric Food Chem 50 (16): 4586-4588.

NF EN 350-1, 1994. Durability of wood and wood-based products -Natural durability of solid wood. Part 1: Guide to the principles of testing and classification of the natural durability of wood. (Brussels, European Committee for Standarization).

NF EN 335-2. 2013. Durability of wood and wood-based products - Definition of use classes of biological attack - Part 2: Application to solid wood. (Brussels, European Committee for Standarization).

NF EN 460, 1994. Durability of wood and wood-based products. Natural durability of solid wood Guide of the the durability requirements for wood to be used in hazard classes. (Brussels, European Committee for Standarization).

Paoli, M.; Nam, A.M.; Castola, V.; Casanova, J.; Bighelli, A. 2011. Chemical variability of the wood essential oil of Cedrus atlantica Manetti from Corsica. Chem Biodivers 8(2):344-351.

Remmal, A.; Tantaoui-Eiaraki, A.; Bouchikhi, T.; Rhayour, K.; Ettayebi, M. 1993. lmproved method for determination of antimicrobial activity of essential oils in agar medium. $J$ Ess Oil Res 5: 179-184.

Rennerfelt, E. 1948. Investigations of Thujaplicine, a fungicidal substance in the heartwood of Thuja plicata D. Don. Physiol Plantarum 1: 245-254.

Rhafouri, R.; Satrani, B.; Zair, T.; Ghanmi, M.; Aafi, A.; El Omari, M.; Bentayab, A. 2014 Chemical composition. antibacterial and antifungal activities of the Cedrus atlantica (Endl.) Manetti seeds essential oils. Mediterranean Journal of Chemestry 3 (5): 1027-1036.

Satrani, B.; Aberchane, M.; Farah, A.; Chaouch, A.; Talbi, M. 2006. Composition chimique et activité antimicrobienne des huiles essentielles extraites par hydrodistillation fractionnée du bois de Cedrus atlantica Manetti. Acta Bo Gallica 153 (1): 97-104.

Takeuchi, M.; Ichishima, E. 1989. Inhibition study of tyrosinase from Aspergillus oryzae. Agric Biol Chem 53: 557-558.

Tantaoui-Elaraki, A.; Lattaoui, N.; Benjilali, B.; Errifi, A. 1992. Antimicrobial activity of four chemically different essential oils. Rivista Italiana E.P.P.O.S. 6: 13-22.

Thevenon, M.F.; Janah, T.; Rahouti, M.; Langbour, P.; Gerard, J. 2012. Investigations on the durability of two secondary Pine species (Pinus halepensis, Pinus uncinata) within the scope of the European natural durability standards revision. IUFRO conference, Division 5 - Forest Products. 8-13 July 2012, Lisbon, Portugal.

Thangadurai, D.; Anitha, S.; Pullaiah, T.; Reddy, P.N.; Ramachandraiah, O.S. 2002. Essential oil constituents and in vitro antimicrobial activity of Decalepis hamiltonii roots against foodborne pathogens. J Agric Food Chem 50: 3147-3149. 